\title{
Sistem Praktik Dokter Online Berbasis Website di Masa Pandemi
}

\author{
Dhiani Tresna Absari ${ }^{1}$, Daniel Soesanto ${ }^{1 *}$ \\ ${ }^{1}$ Teknik Informatika, Fakultas Teknik, Universitas Surabaya, Surabaya-Indonesia \\ * corresponding author: daniel.soesanto@staff.ubaya.ac.id
}

\begin{abstract}
The pandemic period, which has been running for approximately two years, has brought many changes to everyone's lifestyle, including in Indonesia. All forms of mobility that used to be easy to do have turned into limitations during the pandemic. One of the activities that is important but full of limitations is conducting an examination at a doctor's practice. Patients and doctors during this pandemic, of course, feel worried if there is a crowd or accumulation of patients in the doctor's waiting room. In addition, various print media, such as patient medical histories, are also a source of concern because they can be a medium for transmitting the virus. Mobile technology and the growing website should be seen as an opportunity to make this easier. The contribution of this research is to develop a website-based online doctor practice system design that can help facilitate doctors' private practice activities both for patients and for doctors themselves. The validation results show that the system design developed can make it easier for patients to register and visit more safely during a pandemic. As for doctors, it was found that doctors felt very helpful in tracing the patient's medical history safely, completely, and easily.
\end{abstract}

Keywords: doctor, website, online, pandemic

Abstrak-Masa pandemi yang telah berjalan kurang lebih dua tahun, telah membawa banyak perubahan pada pola hidup setiap orang, termasuk di Indonesia. Segala bentuk mobilitas yang dulunya dapat dilakukan dengan mudah, berubah menjadi penuh keterbatasan pada masa pandemi. Salah satu kegiatan yang penting namun penuh keterbatasan adalah melakukan pemeriksaan pada praktik dokter. Pasien maupun dokter pada masa pandemi ini, tentunya merasa khawatir apabila terjadi kerumunan atau penumpukan pasien pada ruang tunggu dokter. Selain itu berbagai media cetak seperti riwayat medis pasien, juga menjadi sumber kekhawatiran karena dapat menjadi media dalam penularan virus. Teknologi mobile dan website yang semakin berkembang harus dipandang sebagai salah satu peluang untuk mempermudah hal ini. Kontribusi dari penelitian ini adalah mengembangkan sebuah desain sistem praktik dokter online berbasis website yang dapat membantu mempermudah aktivitas praktik pribadi dokter baik bagi pasien maupun bagi dokter itu sendiri. Hasil validasi menunjukkan bahwa desain sistem yang dikembangkan dapat mempermudah pasien dalam melakukan pendaftaran dan kunjungan dengan lebih aman di masa pandemi. Sedangkan bagi dokter, didapatkan bahwa dokter merasa sangat terbantu dalam melakukan penelurusan riwayat medis pasien secara aman, lengkap, dan mudah.

Kata kunci: dokter, website, online, pandemi

\section{PENDAHULUAN}

Kunjungan ke dokter adalah aktivitas yang biasa dilakukan oleh orang, apabila mengalami gangguan kesehatan. Salah satu cara untuk mendapatkan layanan kesehatan adalah dengan mengunjungi dokter dengan cara datang langsung ke lokasi tempat praktik pribadi dokter tersebut. Pasien dapat melakukan pendaftaran, menunggu antrean dan sampai kemudian mendapatkan layanan konsultasi medis. Sedangkan dari sisi dokter, akan melakukan pemeriksaan dan analisa terhadap kondisi pasien, lalu memberikan obat, dan tidak lupa pula akan mencatat data-data pemeriksaan tersebut. Pencatatan ini nantinya akan disebut sebagai pencatatan rekam medis (Lau et al., 2000). Media yang digunakan untuk mencatat, kebanyakan masih berupa kertas atau hardcopy (Thomas, 2009). Riwayat ini dapat digunakan oleh dokter maupun pasien untuk mengetahui kondisi pasien, saat pasien tersebut berkunjung kembali suatu waktu nanti, sehingga perawatan lanjutan yang diberikan oleh dokter, dapat sesuai dengan kondisi pasien tersebut (Cimino, Patel \& Kushniruk, 2001; Skolnik et al., 2020; He et al., 2021).

Masa pandemi yang telah berjalan kurang lebih dua tahun telah mengubah sebagian besar pola hidup aktivitas manusia (Chen et al., 2020; Ivanova, Ivanov, \& Ivanov, 2021; Liekefett \& Becker, 2021). Mulai dari aktivitas belajar, bekerja, bersosialisasi, wisata, olah raga hingga dalam hal perawatan kesehatan, semua dilakukan dari rumah. Hal ini juga berdampak negatif secara psikologis maupun secara kemudahan dalam beraktivitas tersebut (Khattar, Jain 
\& Quadri, 2020; Purwanto et al., 2020; Suryaman et al., 2020; Barnett \& Jung, 2021; Lee et al., 2021; Lim \& Pranata, 2021). Salah satu hal yang paling menjadi fokus pada saat pandemi ini adalah menjaga tubuh tetap sehat dan menemukan perawatan serta pengobatan yang tepat pada saat sakit (Arena \& Lavie, 2020; Shah et al., 2020; Wood \& Jóhannsson, 2020). Oleh karena itu kunjungan dokter menjadi salah satu aktivitas yang harus tetap dilakukan atau bahkan makin sering dibutuhkan di masa pandemi ini. Namun dengan adanya berbagai ancaman virus di masa pandemi ini otomatis membuat banyak keterbatasan dalam melakukan kunjungan dokter.

Pada sisi pasien, setiap orang yang akan melakukan kunjungan dokter sekarang ini, pasti akan khawatir juga apabila di tempat praktik dokter itu harus menunggu bersama banyak orang, sehingga terjadi kerumunan. Sedangkan pada sisi dokter kekhawatiran ini juga akan terjadi, karena kerumunan bisa ada di tempat praktiknya yang juga tentu saja dapat membahayakan dokter itu sendiri. Di samping itu, saat dokter membuat pencatatan rekam medis pasien akan terjadi kekhawatiran pula apabila dilakukan di kertas yang kemudian dapat membawa virus ke pasien. Masalah lain yang dapat terjadi pula adalah apabila menggunakan catatan kertas, dokter bisa jadi cukup lama dalam menemukan pencatatan rekam medis pasien. Durasi yang lama dalam mencari informasi ini tentu saja berdampak pada lamanya waktu tunggu dari pasien dan lamanya waktu berkerumun dengan pasien dalam satu ruangan. Hal-hal ini sangat berbahaya, mengingat pada masa pandemi seperti sekarang ini. Salah satu hal penting yang harus dihindari adalah berada di suatu ruangan tertutup bersama dengan orang asing pada jangka waktu yang lama.

Apabila melihat dari perkembangan teknologi yang terjadi saat ini, maka terlihat bahwa teknologi mobile sudah secara dominan menguasai lini kehidupan setiap orang (Urbaczewski \& Lee, 2020; Whitelaw et al., 2020; Akram et al., 2021; Al-zubidi et al., 2021); mulai dari pemesanan transportasi, pemesanan makanan, hingga pendataan vaksinasi pada masa pandemi ini (Herdiana, 2021; Press, Huisingh-Scheetz \& Arora, 2021). Penggunaan teknologi ini makin besar, karena teknologi ini dipandang sebagai peluang yang dapat tetap menghubungkan orang satu sama lain tanpa harus bertemu langsung. Selain itu teknologi mobile yang didukung oleh smartphone ini dapat menjadi media yang sangat baik dalam menghubungkan setiap orang dalam aktivitasnya, karena sebagian besar orang tidak akan meninggalkan smartphone-nya dalam waktu yang lama. Oleh karena itu, dapat dikatakan saat ada seseorang di suatu tempat, maka smartphone pasti ada di tangan atau saku orang tersebut. Namun aplikasi yang murni hanya bisa digunakan di mobile atau smartphone membawa kelemahan baru, yaitu kurangnya informasi yang dapat ditampung dengan jelas pada satu halaman, serta sulitnya mengoperasikan apabila data yang dimasukkan cukup banyak (Maurer et al., 2010; Tupikovskaja-Omovie et al., 2015). Oleh karena itu untuk pengembangan sistem yang membutuhkan tampilan informasi yang detail dan pemasukan data yang banyak lebih tepat apabila menggunakan basis website, namun yang tetap dapat berjalan di mobile.

Kontribusi dari penelitian ini adalah mengembangkan sebuah sistem praktik dokter online berbasis website yang disertai dengan fitur pencarian tempat praktik pribadi dokter berdasarkan berbagai kriteria, fitur pendaftaran, serta fitur pencatatan rekam medis pasien. Perbedaan penelitian ini dengan aplikasi sejenis yang ada saat ini adalah pada penelitian ini dokter akan tetap punya waktu untuk bertatap muka langsung dengan pasien, namun dengan waktu yang lebih efektif. Hal ini dikarenakan pada penelitian ini pasien hanya akan datang, pada saat siap diperiksa, sehingga mengurangi durasi pertemuan langsung dengan dokter. Selain itu pada penelitian ini pasien dimungkinkan untuk melakukan pencarian praktik dokter pribadi berdasarkan berbagai kriteria pencarian yang dibutuhkan. Di samping fitur pendaftaran, pasien juga bisa mendapatkan laporan rekam medis miliknya dalam format yang global. 


\section{METODE}

Urutan aktivitas yang dilakukan pada penelitian ini adalah dimulai dari identifikasi kondisi saat ini, analisis terhadap masalah yang terjadi dengan adanya kondisi saat ini, analisis peluang teknologi yang dapat dimanfaatkan untuk menyelesaikan masalah yang ada, serta alternatif solusi yang dipilih, dan diimplementasikan untuk menyelesaikan masalah tersebut dengan memanfaatkan teknologi informasi.

Pada bagian analisis masalah dipecah lagi menjadi analisis masalah yang ada pada sistem konvensional serta analisis terhadap sistem sejenis yang sudah ada saat ini. Setelah ditemukan detail dari masalah serta kemampuan dari sistem sejenis, maka dirumuskan analisis kebutuhan dari sistem yang akan dikembangkan pada penelitian ini. Bagan dari metode penelitian yang digunakan secara umum dapat dilihat pada Gambar 1. Pada gambar tersebut terlihat bahwa analisis terhadap masalah di sistem konvensional saat ini, masalah pada sistem sejenis, serta analisis terhadap kebutuhan untuk menyelesaikan masalah tersebut, menjadi satu kesatuan utuh. Setelah memahami dengan mendalam masalah yang ada, barulah akan dilakukan analisis terhadap teknologi yang cocok untuk dapat memecahkan masalah tersebut. Alternatif solusi menjadi bagian paling akhir dari bagan secara umum ini.

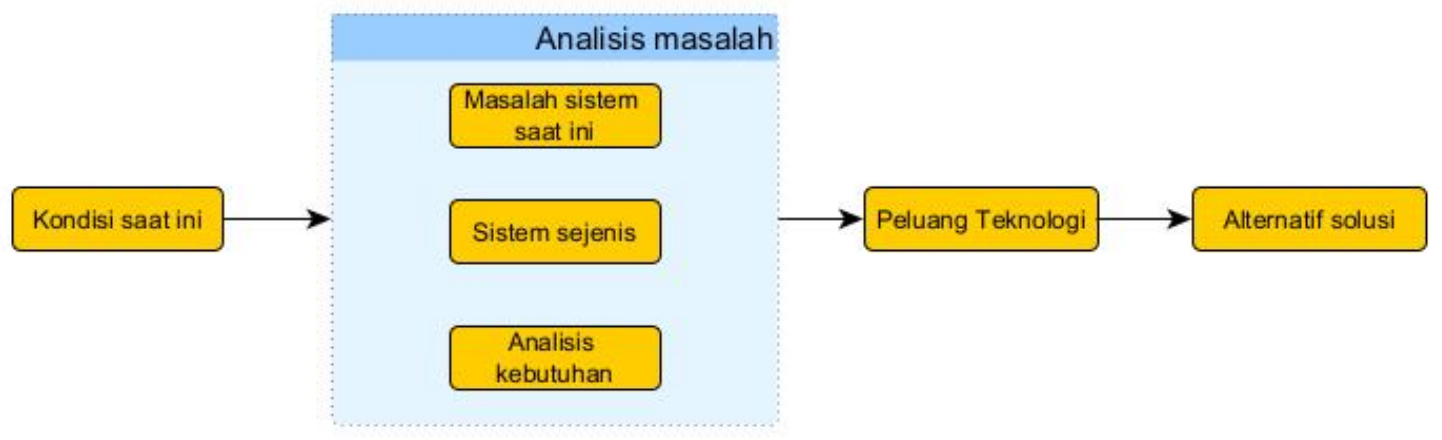

Gambar 1. Bagan pengembangan sistem secara umum.

Pada bagian pengembangan desain sistem dipecah lagi menjadi sub-bagian proses, yang diawali dengan desain data dan relasinya, pengembangan desain sistem melalui desain data yang telah dibuat, verifikasi internal atau uji coba oleh tim peneliti, serta validasi yang dilakukan dengan Teknik wawancara calon pengguna. Wawancara ini dilakukan setelah calon pengguna yang terdiri atas dokter dan pasien, dijelaskan dan ditunjukkan gambaran mendetail terkait sistem yang akan dikembangkan. Pengembangan sistem menggunakan metode Waterfall. Pada metode ini proses pengembangan dilakukan secara berurutan, dan setiap proses hanya dapat dilakukan saat proses sebelumnya telah selesai (Royce, 1970). Detail dari sub-proses pengembangan desain sistem dapat dilihat pada Gambar 2. Pada gambar tersebut terlihat bahwa verifikasi internal akan dilakukan terlebih dahulu sebelum dilakukan validasi terhadap calon pengguna. Hasil verifikasi dan validasi ini digunakan sebagai hasil dari penelitian ini dan akan dirumuskan menjadi kesimpulan penelitian ini.

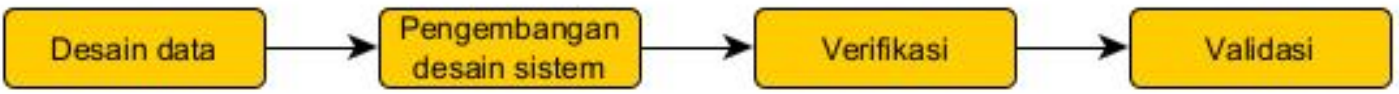

Gambar 2. Bagan sub-proses pengembangan desain system.

Metode wawancara atau kualitatif dipilih karena memiliki beberapa kelebihan yang dibutuhkan oleh penelitian ini yaitu untuk mendapatkan feedback secara detail dari pengguna, lebih cepat dalam pengumpulan data, sangat sesuai apabila digunakan untuk melakukan validasi user experience dan menghindari informasi ambigu yang dapat terjadi pada metode kuantitatif (Kilani and Kobziev, 2016). Selain itu metode interview juga dapat meyakinkan 
bahwa antara peneliti dan target interview memiliki pemikiran yang sudah sama mengenai tujuan interview tersebut (Al-Azri, Al-Salti, \& Al-Karaghouli, 2010).

\section{HASIL}

Teknik wawancara dan penyebaran kuesioner dilakukan sebagai metode pencarian kebutuhan dalam sistem yang akan dirancang (Bently \& Whitten, 2006). Wawancara dilakukan dengan beberapa narasumber dengan profesi dokter yang memiliki tempat praktik pribadi. Tujuan wawancara secara umum adalah untuk mengidentifikasi proses bisnis yang terjadi pada saat konsultasi medis dilakukan. Sementara itu kuesioner yang disebarkan ke beberapa pasien. Kuesioner ini bertujuan untuk memahami mekanisme administrasi konsultasi medis dari sisi pasien. Hasil wawancara dan kuesioner yang dilakukan diharapkan dapat memberikan petunjuk dalam melakukan perancangan sistem.

Berdasarkan wawancara dengan dokter disimpulkan terdapat dua proses bisnis utama pada konsultasi medis di tempat praktik pribadi dokter, yaitu pendaftaran pasien dan pencatatan rekam medis pasien. Pendaftaran pasien dilakukan dengan menghubungi tempat praktik dokter lewat telpon ataupun datang secara langsung. Masing-masing cara ini memiliki kelebihan dan kekurangan. Jika pasien mendaftar lewat telpon, maka pasien akan mendapatkan informasi lebih pasti tentang status pendaftaran. Untuk pasien yang belum memiliki nomer telpon tempat praktik dokter, maka pasien tentu harus mencari nomer telpon tempat praktik dokter dengan berbagai cara. Bisa saja nomer telpon yang dicari belum tentu berhasil ditemukan. Bagi pasien yang melakukan pendaftaran langsung di tempat praktik bisa saja tidak mendapatkan slot konsultasi. Pada saat pendaftaran, pasien harus menyebutkan ID Pasien yang telah terdaftar di tempat praktik dokter (terkadang pasien sendiri lupa ID Pasiennya karena berbagai faktor).

Dari sisi pencatatan rekam medis pada tempat praktik dokter pribadi, mayoritas masih berbasis kertas. Rekam medis secara umum dapat diartikan sebagai dokumen yang mencatat keseluruhan pemeriksaan atau pengobatan yang telah dilakukan oleh pasien, yang berisi data medis pasien dan harus dijaga kerahasiaannya (PERMENKES RI No 269/MENKES/PER/III/2008, 2008). Oleh sebab itu, penyimpanan rekam medis berbasis kertas memiliki beberapa kelemahan, antara lain membutuhkan waktu yang lama dalam pencarian data atau riwayat medis pasien, catatan mudah terselip ataupun usang jika dipergunakan berulang kali. Selain itu, rekam medis yang berbasis kertas yang terkadang juga disertai hasil lab tentu memerlukan tempat khusus untuk menyimpan karena rekam medis bersifat data rahasia. Penyimpanan rekam medis dalam bentuk kertas juga tidak dapat diakses dari berbagai tempat. Hal ini menjadi kendala ketika seorang dokter tidak membawa rekam medis pasien namun perlu mengakses dari luar tempat praktiknya, misalkan ketika melakukan perjalanan maupun ketika berada di Rumah Sakit.

Dari hasil penyebaran kuesioner kepada pasien dari dokter praktik pribadi didapatkan data bahwa berobat pada tempat praktik dokter pribadi cukup diminati karena menjadi pilihan kedua setelah berobat di rumah sakit. Mayoritas pasien kesusahan mendapatkan informasi alternatif tempat praktik dokter pribadi karena biasanya banyak pasien yang mendapatkan informasi praktik dokter pribadi berdasarkan rekomendasi. Dari sisi pendaftaran $75 \%$ pasien mengharapkan dapat melakukan pendaftaran sebelumnya dari rumah dibandingkan harus datang secara langsung untuk mendaftar. Hampir $70 \%$ pasien enggan atau tidak menyimpan hasil lab dan rata-rata pasien tidak dapat secara global mengetahui riwayat pemeriksaan ketika berobat.

Berdasarkan uraian analisis tersebut dapat diidentifikasikan beberapa kebutuhan sistem. Kebutuhan sistem yang utama antara lain: (a) fitur informasi tempat praktik dokter dengan berbagai kriteria pencarian, meliputi lokasi menggunakan google map api dan informasi spesialisasi dan sub-spesialisasi, keahlian, jarak, tarif konsultasi dan lain sebagainya; (b) fitur pendaftaran dan estimasi waktu layanan; (c) fitur pencatatan rekam medis dan hasil lab yang dienkripsi; (d) laporan rekam medis untuk pasien. Desain sistem meliputi desain data, 
desain user interface dan desain proses. Desain data diwujudkan dalam bentuk Entity Relationship Diagram (ERD) seperti ditunjukkan pada Gambar 3 berikut ini.

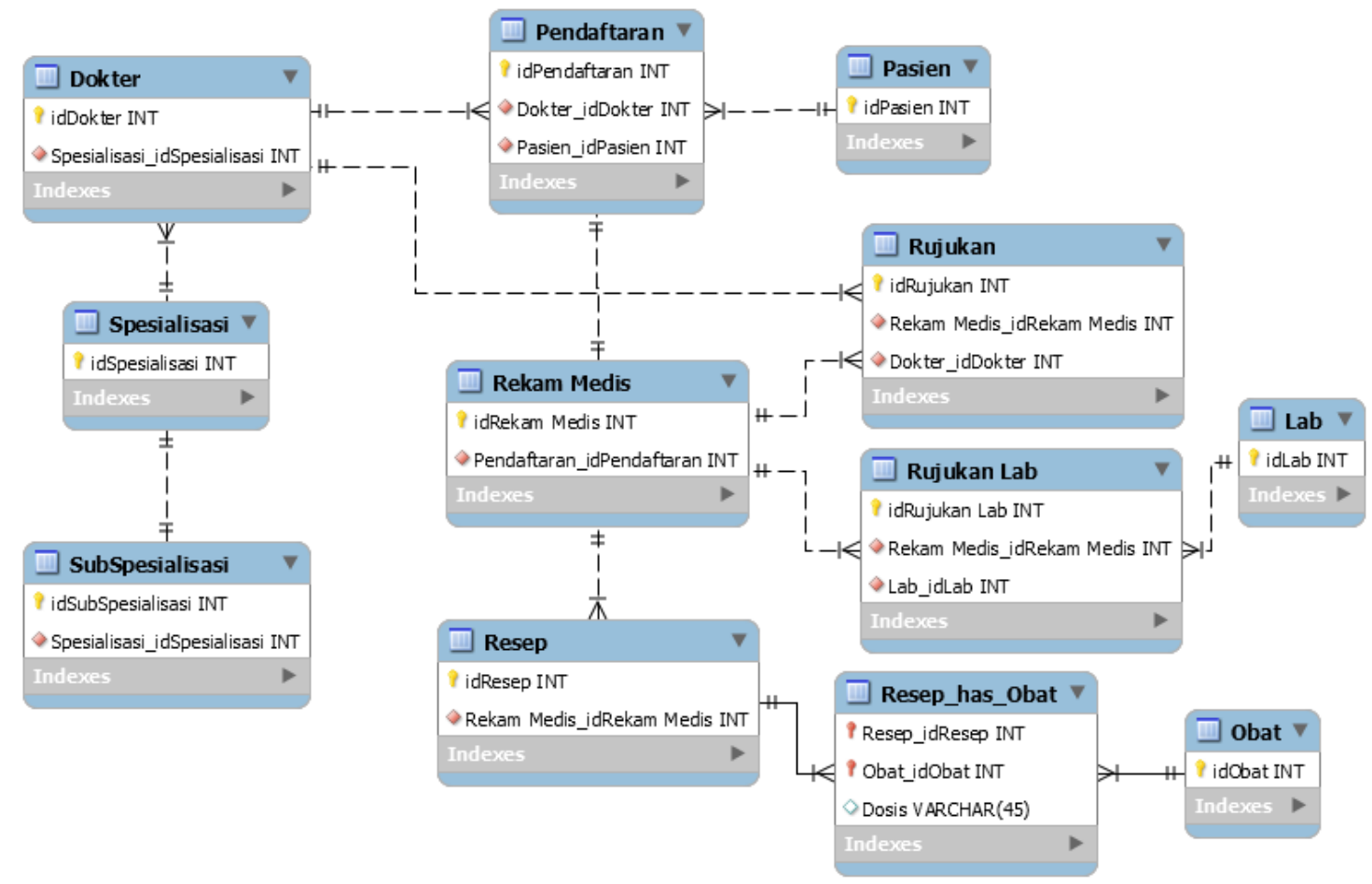

Gambar 3. ERD System yang dikembangkan.

Penjelasan ERD tersebut adalah dokter dapat memiliki spesialis dan sub-spesialis. Dokter juga dapat membuka pendaftaran konsultasi medis. Setiap hasil konsultasi akan dicatat di rekam medis. Rekam medis dapat memberikan rujukan dokter dan atau lab serta resep.

Secara garis besar, proses bisnis sistem yang dikembangkan dimulai dari proses pendaftaran. Pada proses pendaftaran, pasien dapat melihat berbagai alternatif dokter berdasarkan kriteria filter yang diinputkan dan kemudian dapat memilih jadwal dokter untuk melakukan konsultasi. Selanjutnya sistem mengonfirmasikan waktu untuk konsultasi. Ketika konsultasi kemudian dilakukan, dokter dapat menginputkan hasil scan atau foto laboratorium untuk melengkapi data rekam medis yang diinputkan ke dalam sistem. Jika diperlukan rujukan maupun pengantar lab, dokter dapat menginputkan ke dalam sistem sehingga dapat dicetak baik oleh dokter maupun pasien. Salah satu bentuk laporan yang dapat dihasilkan sistem adalah laporan rekam medis misalnya. Namun informasi pada laporan rekam medis ini tentu berbeda tingkat detilnya bergantung dari user yang mengakses apakah dokter atau pasien. Berikut ini adalah rancangan dari dua desain proses utama dari sistem yang dikembangkan. Gambar 4 menjelaskan alur proses pendaftaran dan Gambar 5 menjelaskan alur pencatatan rekam medis. 


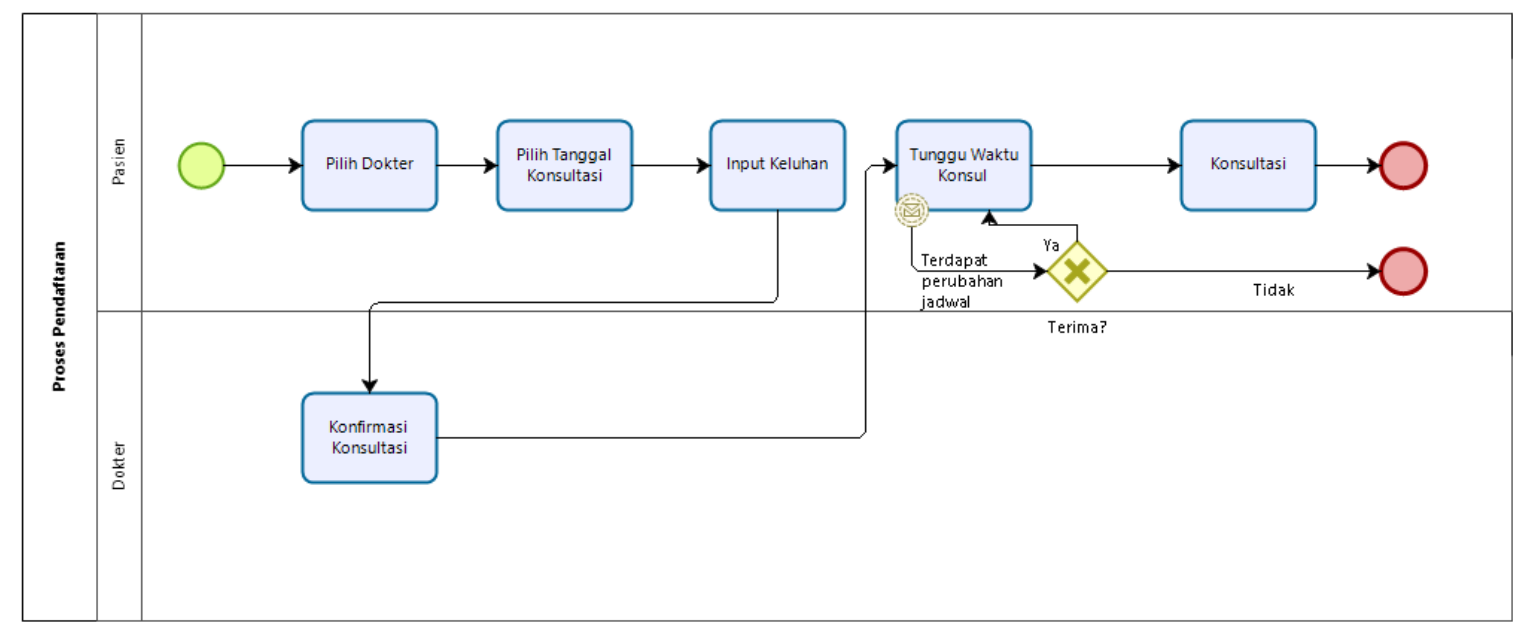

Gambar 4 Alur proses pendaftaran.

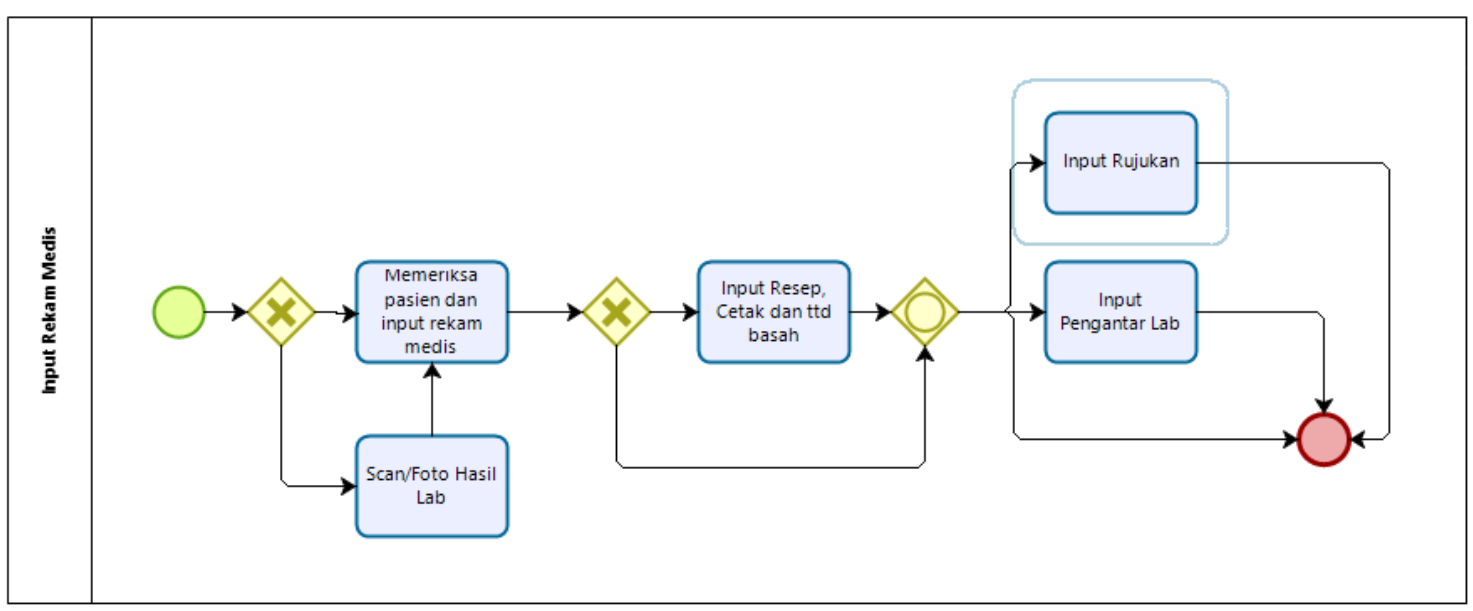

Gambar 5. Alur proses input rekam medis.

Pada konsep desain user interface dikenal konsep Fidelity. Fidelity pada aspek desain menggambarkan tata letak teks, gambar, konten, sehingga dapat menguji interpretasi pengguna dalam bentuk fidelity prototype (Walker, Takayama, \& Landay, 2002). Terdapat dua jenis fidelity yaitu low fidelity dan high fidelity. Low fidelity prototype menggambarkan sistem dengan karakteristik mempunyai fungsi atau interaksi yang terbatas. Contoh low fidelity prototype adalah wireframe dan storyboarding. Sementara High fidelity prototype menggambarkan desain dengan lebih rinci lagi dan mendekati produk jadi. High fidelity prototype biasanya dikembangkan dengan menggunakan alat bantu desain user interface. High fidelity prototype sangat membantu dalam proses validasi desain sistem terhadap user juga membantu dalam proses implementasi sistem.

Desain form dilakukan dengan membuat high fidelity prototype yang bertujuan untuk mempermudah validasi rancangan sistem terhadap user. Desain proses bisnis yang telah dijelaskan sebelumnya dapat dilihat pada gambar-gambar berikut ini. Pertama pasien dapat melakukan pencarian alternatif dokter sesuai dengan beberapa filter, antara lain: jarak, spesialis, sub-spesialis, dan keahlian spesifik yang dimiliki dokter, seperti yang terlihat di Gambar 6. Data dokter yang berhasil difilter akan tampil lokasinya dalam bentuk pin lokasi pada peta, serta list dokter yang dapat dipilih berdasarkan harga dan jarak (Gambar 7). Kemudian, pasien dapat memilih dokter yang dikehendaki dan kemudian melakukan pendaftaran. Gambar 8 menunjukkan form Rekam Medis yang diakses dokter dalam proses pemeriksaan medis. Data akan dienkripsi sebelum tersimpan di dalam database untuk memastikan keamanan informasinya. 


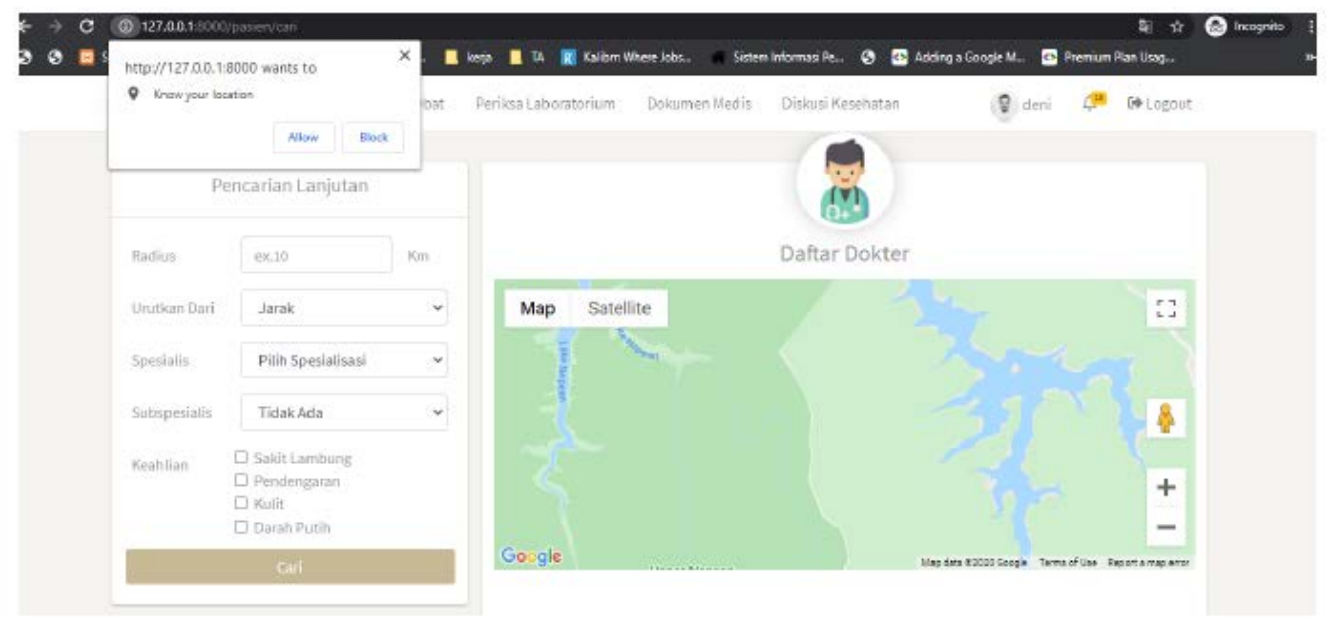

Gambar 6. Halaman pencarian daftar dokter.

\begin{tabular}{|c|c|c|}
\hline \multirow{6}{*}{\multicolumn{2}{|c|}{$\begin{array}{l}\text { ayu } \\
\text { U, Spesialis Anak|General } \\
\text { Pendengaran,Sakit Lambung } \\
\text { 욜 Rungkut Mejoyo Sel., Kali Rungkut, Kec. Rungkut, } \\
\text { Kota SBY, Jawa Timur, Indonesia } \\
4.06 \mathrm{~km}\end{array}$}} & \multirow{3}{*}{$\begin{array}{l}\text { Minimal Biaya } \\
\text { Periksa } \\
\text { Rp100.000 }\end{array}$} \\
\hline & & \\
\hline & & \\
\hline & & \multirow[t]{3}{*}{ Pilih $\mathrm{A}$} \\
\hline & & \\
\hline & & \\
\hline \multicolumn{2}{|c|}{ andrew } & \multirow{3}{*}{$\begin{array}{l}\text { Minimal Biaya } \\
\text { Periksa } \\
\text { Rp100.000 }\end{array}$} \\
\hline & \multirow{5}{*}{$\begin{array}{l}\text { Spesialis Anak|General } \\
\text { Pendengaran, Sakit Lambung } \\
\text { Rungkut Mejoyo Utara AG 19, Kali Rungkut, Kec } \\
\text { Rungkut, Kota SEY, Jawa Timur 60292, Indonesia } \\
4.26 \mathrm{~km}\end{array}$} & \\
\hline & & \\
\hline & & Pilih \\
\hline & & \\
\hline & & \\
\hline
\end{tabular}

Gambar 7. Halaman detail daftar dokter. 

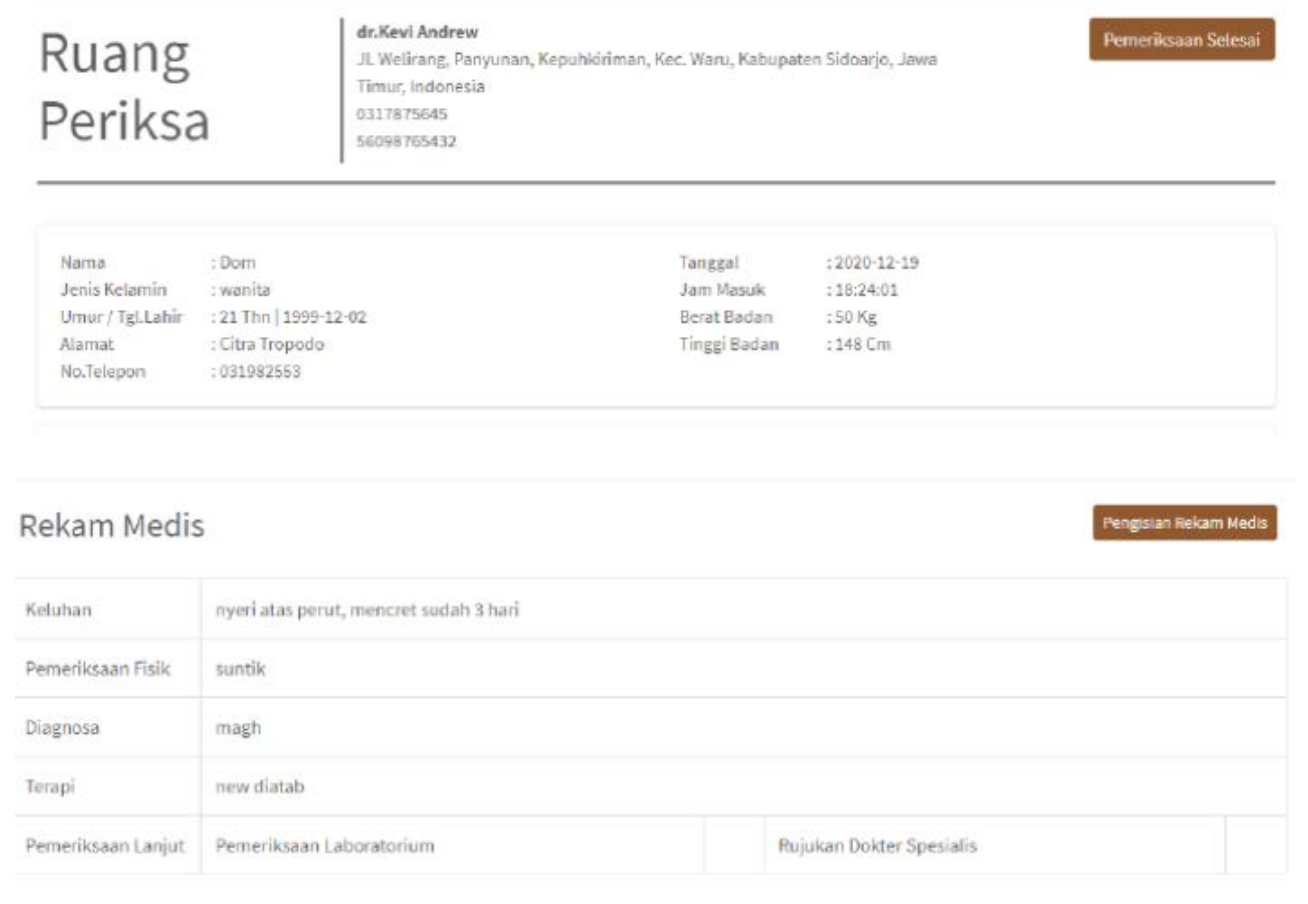

Gambar 8. Halaman rekam medis.

\section{BAHASAN}

Ujicoba dilakukan dengan teknik wawancara dengan terlebih dahulu menjelaskan alur dari proses bisnis yang ada sesuai kebutuhan sistem serta menunjukkan hasil desain form yang dirancang dalam bentuk high fidelity prototype. Berdasarkan hasil wawancara dengan user dokter didapatkan kesimpulan bahwa sistem telah dapat membantu proses administrasi pendaftaran dan pencatatan rekam medis. Data rekam medis dapat tersimpan dengan aman di sistem. Selain itu sistem juga dinilai dapat memberikan informasi keberadaan tempat praktik pribadi mereka serta keahlian mereka kepada masyarakat yang membutuhkan.

Dari sisi user pasien, hasil wawancara menyimpulkan bahwa pasien cukup terbantu dengan adanya informasi lokasi, keahlian, spesialisasi dampai estimasi tarif periksa yang ada pada sistem ini, karena memungkinkan pasien untuk mendapatkan banyak alternatif pilihan dokter. Pendaftaran secara online juga dinilai sangat membantu karena dapat status konsultasi pasien jadi lebih pasti. Pasien juga sangat senang dengan adanya laporan rekam medis yang dapat memberikan gambaran secara global tentang sejarah kesehatan mereka. Berdasarkan hasil wawancara, sistem dinilai secara umum telah dapat membantu dokter dan pasien dalam mempermudah melakukan transaksi pelayanan kesehatan yang dibutuhkan.

\section{SIMPULAN}

Penelitian yang dilakukan telah menghasilkan sebuah desain sistem yang dapat membantu praktik pribadi dokter, baik dari segi pasien maupun dokter itu sendiri. Hasil verifikasi dan validasi yang dilakukan menunjukkan bahwa pasien sudah dapat menemukan dokter dengan mudah serta mendaftar dengan mudah. Selain itu pada sisi dokter, juga dimudahkan dengan adanya sistem pencatatan riwayat medis dari pasien. Desain sistem ini secara umum sudah dapat mengurangi durasi tatap muka dari dokter dan pasien, tanpa mengurangi efektivitas dari pemeriksaan atau diagnosa yang dilakukan oleh dokter. Implikasi dari desain sistem yang dikembangkan adalah mampu memberikan rasa aman baik bagi dokter maupun pasien untuk tetap menjalankan fungsinya masing-masing di masa pandemi ini.

Hal yang masih menjadi batasan dari penelitian ini adalah belum adanya jaminan validitas data dokter maupun pasien yang mendaftar. Oleh karena itu dibutuhkan penelitian 
lebih lanjut untuk menambahkan desain sistem validasi identitas dari dokter dan pasien, sehingga tingkat kepercayaan dari sistem ini dapat lebih meningkat.

\section{PUSTAKA ACUAN}

Akram, U. et al. (2021) 'Impact of digitalization on customers' well-being in the pandemic period: Challenges and opportunities for the retail industry', International Journal of Environmental Research and Public Health, 18(14). doi: 10.3390/ijerph18147533.

Al-Azri, A., Al-Salti, Z. and Al-Karaghouli, W. (2010) 'The successful implementation of egovernment transformation: A case study in Oman', Proceedings of the European, Mediterranean and Middle Eastern Conference on Information Systems: Global Information Systems Challenges in Management, EMCIS 2010, (October 2014).

Al-zubidi, A. F. et al. (2021) 'Mobile Application to Detect Covid-19 Pandemic by Using Classification Techniques: Proposed System', International Journal of Interactive Mobile Technologies, 15(16), pp. 34-51. doi: 10.3991/ijim.v15i16.24195.

Arena, R. and Lavie, C. J. (2020) 'The global path forward - Healthy Living for Pandemic Event Protection (HL - PIVOT)', (January).

Barnett, W. S. and Jung, K. (2021) 'Seven Impacts of the Pandemic on Young Children and Their Parents: Initial Findings from NIEER's December 2020 Preschool Learning Activities Survey. Research Report', National Institute for Early Education Research, (February), pp. $1-12$.

Bently, L. D. and Whitten, J. L. (2006) Systems Analysis and Design for the Global Enterprise. 7th edn. McGraw-Hill.

Chen, X. et al. (2020) 'Changes in psychological wellbeing, attitude, and information-seeking behavior among people at the epicenter of the COVID-19 pandemic: A panel survey of residents in Hubei province, China', Epidemiology and Infection, (2020). doi: 10.1017/S0950268820002009.

Cimino, J. J., Patel, V. L. and Kushniruk, A. W. (2001) 'What do patients do with access to their medical records?', Studies in Health Technology and Informatics, 84, pp. 1440-1444. doi: 10.3233/978-1-60750-928-8-1440.

He, X. et al. (2021) 'The design of electronic medical records for patients of continuous care', Journal of Infection and Public Health, 14(1), pp. 117-122. doi: 10.1016/j.jiph.2019.07.013.

Herdiana, D. (2021) 'Aplikasi Peduli Lindungi: Perlindungan Masyarakat Dalam Mengakses Fasilitas Publik Di Masa Pemberlakuan Kebijakan Ppkm', Jurnal Inovasi Penelitian, 2(6), pp. 1685-1694.

Ivanova, M., Ivanov, I. K. and Ivanov, S. (2021) 'Travel behaviour after the pandemic: the case of Bulgaria', Anatolia, 32(1), pp. 1-11. doi: 10.1080/13032917.2020.1818267.

Khattar, A., Jain, P. R. and Quadri, S. M. K. (2020) 'Effects of the Disastrous Pandemic COVID 19 on Learning Styles, Activities and Mental Health of Young Indian Students-A Machine Learning Approach', Proceedings of the International Conference on Intelligent Computing and Control Systems, ICICCS 2020, (Iciccs), pp. 1190-1195. doi: 10.1109/ICICCS48265.2020.9120955.

Kilani, M. Al and Kobziev, V. (2016) 'An Overview of Research Methodology in Information System (IS)', OALib, 03(11), pp. 1-9. doi: 10.4236/oalib.1103126.

Lau, H. S. et al. (2000) 'The completeness of medication histories in hospital medical records of patients admitted to general internal medicine wards', British Journal of Clinical Pharmacology, 49(6), pp. 597-603. doi: 10.1046/j.1365-2125.2000.00204.x.

Lee, S. J. et al. (2021) 'Parenting activities and the transition to home-based education during the COVID-19 pandemic', Children and Youth Services Review, 122(July 2020), p. 105585. doi: 10.1016/j.childyouth.2020.105585.

Liekefett, L. and Becker, J. (2021) 'Compliance with governmental restrictions during the coronavirus pandemic: A matter of personal self-protection or solidarity with people in 
risk groups?', British Journal of Social Psychology, 60(3), pp. 924-946. doi: 10.1111/bjso.12439.

Lim, M. A. and Pranata, R. (2021) 'Sports activities during any pandemic lockdown', Irish Journal of Medical Science, 190(1), pp. 447-451. doi: 10.1007/s11845-020-02300-9.

Maurer, M.-E. et al. (2010) 'Mobile or desktop websites?', p. 739 . doi: 10.1145/1868914.1869018.

PERMENKES RI No 269/MENKES/PER/III/2008 (2008) 'permenkes ri 269/MENKES/PER/III/2008', Permenkes Ri No 269/Menkes/Per/lii/2008, p. 7.

Press, V. G., Huisingh-Scheetz, M. and Arora, V. M. (2021) 'Inequities in Technology Contribute to Disparities in COVID-19 Vaccine Distribution', JAMA Health Forum, 2(3), p. e210264. doi: 10.1001/jamahealthforum.2021.0264.

Purwanto, A. et al. (2020) 'Impact of Work From Home (WFH) on Indonesian Teachers Performance During the Covid-19 Pandemic: An Exploratory Study', International Journal of Advanced Science and Technology, 29(5), pp. 6235-6244.

Royce, W. W. (1970) 'Managing the Development of Large Software Systems (1970)', in Proceedings of IEEE WESCON. Los Angeles, pp. 328-338. doi: $10.7551 /$ mitpress/12274.003.0035.

Shah, K. et al. (2020) 'Focus on Mental Health During the Coronavirus (COVID-19) Pandemic: Applying Learnings from the Past Outbreaks', Cureus, 12(3). doi: 10.7759/cureus.7405.

Skolnik, A. A. et al. (2020) 'Roadblocks to PrEP: What Medical Records Reveal About Access to HIV Pre-exposure Prophylaxis', Journal of General Internal Medicine, 35(3), pp. 832-838. doi: 10.1007/s11606-019-05475-9.

Suryaman, M. et al. (2020) 'COVID-19 pandemic and home online learning system: Does it affect the quality of pharmacy school learning?', Systematic Reviews in Pharmacy, 11(8), pp. 524-530. doi: 10.31838/srp.2020.8.74.

Thomas, J. (2009) 'Medical records and issues in negligence', Indian Journal of Urology, 25(3), pp. 384-388. doi: 10.4103/0970-1591.56208.

Tupikovskaja-Omovie, Z. et al. (2015) 'Mobile app versus website: A comparative eye-tracking case study', International Journal of Social, Behavioral, Educational, Economic, Business and Industrial Engineering, 9(10), pp. 3251-3258.

Urbaczewski, A. and Lee, Y. J. (2020) 'Information Technology and the pandemic: a preliminary multinational analysis of the impact of mobile tracking technology on the COVID-19 contagion control', European Journal of Information Systems, 29(4), pp. 405-414. doi: 10.1080/0960085X.2020.1802358.

Walker, M., Takayama, L. and Landay, J. A. (2002) 'High-Fidelity or Low-Fidelity, Paper or Computer? Choosing Attributes when Testing Web Prototypes', Proceedings of the Human Factors and Ergonomics Society Annual Meeting, 46(5), pp. 661-665. doi: $10.1177 / 154193120204600513$.

Whitelaw, S. et al. (2020) 'Applications of digital technology in COVID-19 pandemic planning and response', The Lancet Digital Health, 2(8), pp. e435-e440. doi: 10.1016/S25897500(20)30142-4.

Wood, T. R. and Jóhannsson, G. F. (2020) 'Metabolic health and lifestyle medicine should be a cornerstone of future pandemic preparedness', Lifestyle Medicine, 1(1), pp. 1-5. doi: 10.1002/lim2.2. 